Emily Brontë: Wuthering Heights 
ANALYSING TEXTS

General Editor: Nicholas Marsh

Chaucer: The Canterbury Tales Gail Ashton

Shakespeare: The Tragedies Nicholas Marsh

Virginia Woolf: The Novels Nicholas Marsh

Jane Austen: The Novels Nicholas Marsh

Charlotte Brontë: The Novels Mike Edwards

Emily Brontë: Wuthering Heights Nicholas Marsh

Further titles are in preparation

\footnotetext{
Analysing Texts

Series Standing Order ISBN 978-0-333-73260-1

(outside North America only)
}

You can receive future titles in this series as they are published by placing a standing order. Please contact your bookseller or, in case of difficulty, write to us ar the address below with your name and address, the title of the series and the ISBN quoted above.

Customer Services Department, Macmillan Distribution Lrd

Houndmills, Basingstoke, Hampshire RG21 6XS, England 


\section{Emily Brontë:}

Wuthering Heights

NICHOLAS MARSH

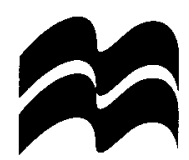


(C) Nicholas Marsh 1999

All rights reserved. No reproduction, copy or transmission of this publication may be made without written permission.

No paragraph of this publication may be reproduced, copied or transmitted save with written permission or in accordance with the provisions of the Copyright, Designs and Patents Act 1988, or under the terms of any licence permitting limited copying issued by the Copyright Licensing Agency, 90 Tottenham Court Road, London W1P 9HE.

Any person who does any unauthorised act in relation to this publication may be liable to criminal prosecution and civil claims for damages.

The aurhor has asserted his right to be identified as the author of this work in accordance with the Copyright, Designs and Patents Act 1988.

First published 1999 by

MACMILLAN PRESS LTD

Houndmills, Basingstoke, Hampshire RG21 6XS

and London

Companies and representatives

throughout the world

ISBN 978-0-333-73731-6

ISBN 978-1-349-27724-7 (eBook)

DOI 10.1007/978-1-349-27724-7

A catalogue record for this book is available from the British Library.

This book is printed on paper suitable for recycling and made from fully managed and sustained forest sources.

$\begin{array}{rrrrrrrrrr}10 & 9 & 8 & 7 & 6 & 5 & 4 & 3 & 2 & 1 \\ 08 & 07 & 06 & 05 & 04 & 03 & 02 & 01 & 00 & 99\end{array}$

Published in the United States of America 1999 by

ST. MARTIN'S PRESS, INC.,

Scholarly and Reference Division,

175 Fifth Avenue, New York, N.Y. 10010

ISBN 978-0-312-22376-2 clothbound

ISBN 978-0-312-22377-9 paperback 
For Bertie 


\section{Contents}

General Editor's Preface $\quad$ x

A Note on Editions $\quad$ xi

PART 1: ANALYSING WUTHERING HEIGHTS

1 The Narrative Frame 3

Narrators 5

[a] Lockwood 5

Analysis: Wuthering Heights, pp. 4-6 5

[b] Nelly Dean 11

Analysis: Wuthering Heights, pp. 164-7 11

[c] Other Narrators 19

Heathcliff. Analysis: Wuthering Heights, pp. 148-9 19

Isabella. Analysis: Wuthering Heights, pp. 178-9 23

A 'Dramatic' Work 26

Conclusions 30

Methods of Analysis 31

Suggested Work 33

2 Characterisation $\quad 34$

Secondary Characters $\quad 35$

Joseph $\quad 35$

Hindley Earnshaw $\quad 36$

Heathcliff 39

Analysis: Wuthering Heights, pp. 285-8 40

Analysis: Wuthering Heights, pp. 320-2 52

Catherine $\quad 62$

Analysis: Wuthering Heights, pp. 122-4 62

Concluding Discussion $\quad 70$

Psychology and Character in Wuthering Heights $\quad 70$

Heathcliff, Catherine and Wuthering Heights $\quad 72$

Methods of Analysis $\quad 76$

$\begin{array}{ll}\text { Suggested Work } & 77\end{array}$ 
3 Imagery and Symbols $\quad 78$

Imagery $\quad 78$

Example: 'foliage' and 'rocks' 79

Example: 'Devil daddy' 84

Symbolism $\quad 88$

Example: Penistone Craggs $\quad 89$

Example: Isabella's dog 91

Example: Gardening at the Heights 99

Conclusions 103

Methods of Analysis $\quad 104$

Suggested Work 105

4 Structure in Wuthering Heights 106

Time $\quad 107$

Families and Social 'Structure' 112

Structure in the Setting $\quad 118$

Conclusions $\quad 124$

Methods of Analysis $\quad 125$

Suggested Work 126

5 Themes 127

Lockwood's Dreams 129

Analysis: Wuthering Heights, pp. 22-6 129

Analysis: Wuthering Heights, pp. 158-60 146

Analysis: Wuthering Heights, pp. 310-11 151

Absolutes and Limitations 154

Concluding Discussion 160

Methods of Analysis $\quad 161$

Suggested Work 162

6 Conclusions to Part $1 \quad 164$

Wuthering Heights: What Sort of a Novel is it? $\quad 164$

How to Study Wuthering Heights 170

Formulating your ideas as questions to ask of
the text

Using summaries $\quad 172$

Studying the 'Structure' and 'Themes' of

Wuthering Heights 


\section{PART 2: THE CONTEXT AND THE CRITICS}

7 Emily Brontë's Life and Works

Emily Brontë's Life

Emily Brontë's Works

The poems

8 The Place of Wuthering Heights in English Literature

The 'Gothic' in Wuthering Heights

'Modernist' Novels

Wuthering Heights and Tragedy

Wuthering Heights and the Development of Setting 204

Concluding Discussion

9 A Sample of Critical Views

David Cecil 209

Terry Eagleton

213

Sandra Gilbert 


\section{General Editor's Preface}

This series is dedicated to one clear belief: that we can all enjoy, understand and analyse literature for ourselves, provided we know how to do it. How can we build on close understanding of a short passage, and develop our insight into the whole work? What features do we expect to find in a text? Why do we study style in so much detail? In demystifying the study of literature, these are only some of the questions the Analysing Texts series addresses and answers.

The books in this series will not do all the work for you, but will provide you with the tools, and show you how to use them. Here, you will find samples of close, detailed analysis, with an explanation of the analytical techniques utilised. At the end of each chapter there are useful suggestions for further work you can do to practise, develop and hone the skills demonstrated and build confidence in your own analytical ability.

An author's individuality shows in the way they write: every work they produce bears the hallmark of that writer's personal 'style'. In the main part of each book we concentrate therefore on analysing the particular flavour and concerns of one author's work, and explain the features of their writing in connection with major themes. In Part 2 there are chapters about the author's life and work, assessing their contribution to developments in literature; and a sample of critics' views are summarised and discussed in comparison with each other. Some suggestions for further reading provide a bridge towards further critical research.

Analysing Texts is designed to stimulate and encourage your critical and analytic faculty, to develop your personal insight into the author's work and individual style, and to provide you with the skills and techniques to enjoy at first hand the excitement of discovering the richness of the text. 


\section{A Note on Editions}

References to Wuthering Heights give the page number from the Penguin Classics edition of 1995, edited with an Introduction and Notes by Pauline Nestor. This edition keeps the original numbering of chapters, beginning at a 'Chapter 1', for each of the three volumes that were originally published. Where there might be any confusion as to which chapter is referred to, I have specified thus: 'Volume 2, Chapter 3'. 